Preprints of the

Max Planck Institute for

Research on Collective Goods

Bonn 2010/35

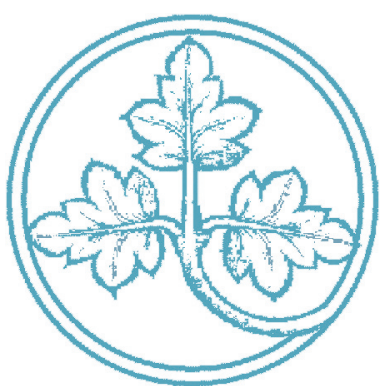

Poverty and crime in

19th century Germany:

A reassessment

Christian Traxler

Carsten Burhop

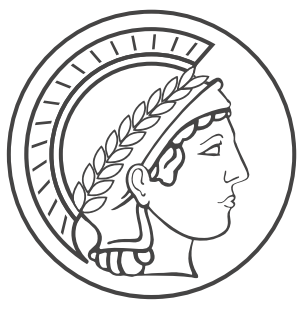




\section{Poverty and crime in 19th century Germany: A reassessment}

Christian Traxler / Carsten Burhop

June 2010 


\title{
Poverty and crime in 19th century Germany:
}

\section{A reassessment ${ }^{*}$}

\author{
Christian Traxler \\ Max Planck Institute for Research on Collective Goods
}

\section{Carsten Burhop}

University of Cologne, Institute of Economic and Business History, and

Max Planck Institute for Research on Collective Goods

August 2010

\begin{abstract}
:
Using panel data for Prussia during 1882 to 1910, we replicate Mehlum, Miguel, and Torvik’s (2006) study on the causal effect of poverty on crime in 19th century Germany. In addition, our data set allows us to make several original contributions to the literature. We confirm the robust positive effect of poverty on property crime. Employing the rye price as a proxy for poverty, we show that the effect is less pronounced for provinces with a large agricultural sector. As Mehlum et al., we also find a strong negative impact of poverty on violent crime. However, once we account for beer consumption, this effect vanishes.
\end{abstract}

Keywords: Poverty; crime; rye price; beer; weather; Prussia.

JEL classification: K42; I33; N93

\footnotetext{
* We would like to thank Christoph Engel, Markus Englerth and Oliver Himmler as well as seminar participants in Bonn and Mannheim for helpful comments. Natalia Mathyl and Carina Woodage provided excellent research assistance. The usual disclaimer applies.

Email: traxler@coll.mpg.de (corresponding author), burhop@wiso.uni-koeln.de.
} 


\section{Introduction}

This paper re-examines the findings of Mehlum, Miguel and Torvik (2006) who study the causal effect of poverty on crime in 19th century Germany. Mehlum et al. (henceforth MMT) analyze the poverty-crime link based on a time series for Bavaria for the years 1835-1861. Their main poverty measure is the rye price. Rye bread was then the staple food and prices for rye were a key determinant of the cost of living. Based on an innovative identification strategy - using rainfall as an instrument for rye prices - MMT identify a strong positive effect of rye prices on property crime, but an even stronger negative effect on violent crime. In interpreting the latter finding, MMT argue "that it is not the case that poverty per se leads to less violent crime, but rather that beer is also expensive in years of high rye prices and the resulting reduction in beer consumption is the likely channel that reduces violent crime” (MMT, p.373).

Our analysis provides a reassessment of their findings and, by explicitly considering the role of beer consumption, tests their interpretation. In doing so, we use a panel on crime rates, rye prices, real wages and beer production for the Prussian provinces for the period 1882-1910. Following the identification strategy of MMT, we collected monthly data on rainfall and temperatures for 13 meteorological stations all over Prussia. The data allow us to extend the original analysis from a time series to panel data. Moreover, using seasonal variation in weather conditions within a (contemporary or lagged) year, we can implement a refined instrumentation of rye prices, real wages and beer production.

Our results strongly confirm the findings of MMT as well as their interpretation of the counterintuitive effect of rye prices on violent crime. Firstly, higher rye prices or lower real wages lead to significantly more property crime. The estimated elasticity of property crime with respect to the rye price [the real wage] of $0.27[-0.70]$ is almost identical to the original estimates obtained by MMT. Extending the existing evidence, our data also reveal that the effect of the rye price is substantially weaker in provinces with a large agrarian sector. This observation perfectly fits the picture, as the living quality of the rural population was less sensitive to the rye price: landless rural workers were typically provided board and lodging by their employers (land owners), and those who owned some land assured a minimum level of self-supply by cultivating their land. It is therefore not surprising that the link between rye prices and property crime is stronger for the more urban provinces. 
Second, as MMT we find a strong and highly significant negative effect of rye prices [positive effect of wages] on violent crimes. This counterintuitive finding is obtained in OLS and 2SLS fixed effects estimation and the estimated elasticity is again remarkably close to the one reported in MMT. Once we control for regional beer production, the effect of rye price and the real wage reduces by about two thirds. In line with evidence on modern data (e.g., Markowitz, 2005), the proxy for beer consumption has a strong and highly significant impact on violent crimes. In contrast, the poverty measures are either statistically insignificant or only borderline significant. This last observation confirms the conjecture by MMT: when we account for a proxy for beer consumption, the two poverty measures have no significant effect on violent crime. Poverty per se does not lead to less violent crime.

From a methodological perspective, our main contribution is to demonstrate that MMT's interpretation of the puzzling negative effect of poverty on violent crime was correct. Although rainfall provides an exogenous source of variation in the rye prices, it is not necessarily a valid instrument as weather conditions also have an impact on beer consumption. Thus, as conjectured by MMT, the weather instruments are correlated with the omitted variable alcohol consumption, which in turn is strongly correlated with violent crime. This pattern resembles the analysis of unemployment and crime in Raphael and Winter-Ebmer (2001). Using US state-level panel data for the period 1971-1997, they find - next to a positive impact on property crimes - a strong negative effect of unemployment on murder and on rape. Similar as in MMT, the effect appears in OLS and in 2SLS estimations. The authors discuss evidence which suggests that this counterintuitive finding is also driven by the correlation of the instruments with an omitted variable. In their case, high employment levels seem to be correlated with a more frequent exposure of potential victims to potential offenders. As noted by Raphael and Winter-Ebmer (2001), any instrument that is correlated with unemployment will be correlated with the unobserved frequency of potential victim-offender interactions and is therefore invalid.

The paper is structured as follows. In Section 2, we describe the historical background and the data sources. Section 3 outlines our estimation approach and Section 4 presents our results. A brief discussion concludes the paper. 


\section{Historical background and data}

\subsection{Historical background}

As a major difference to MMT, who work with data from Bavaria for 1835-1861, we employ Prussian data for the period of 1882-1910. Prussia, covering large parts of today's Germany (as well as parts of the Czech Republic, Lithuania, Poland and Russia), was Germany’s largest state. In 1910, 40 million out of 65 million Germans lived in Prussia, which was subdivided into 12 provinces and the city of Berlin. The provinces differed in size, ranging from 1.6 million (Schleswig-Holstein) to 7.1 million inhabitants (Rhineland), but also with respect to social and economic conditions: some provinces were - similar to Bavaria - dominated by agriculture (e.g., East Prussia, Posen), others by industry (e.g., Berlin, Rhineland). The prevalence of crime also varied substantially between provinces: the eastern regions of Prussia typically had rates of property crime that were twice as high compared to the western provinces. A similar pattern holds for violent crime, however, the differences were less pronounced.

Modern historians focus on poverty as the main explanation of crime in 19th century Germany (see the review by Johnson, 1995). Blasius (1976), for instance, argued that a positive relationship between rye prices and crime existed in mid-19th century Prussia. According to his interpretation, high rye prices were an indicator of low real income, which in turn led to more property crime. A similar correlation was noted by Zehr (1976). While these contributions suggest that we should find this correlation in our data, it remains an open question whether the results from MMT, who identify a causal relationship, extend to late 19th and early 20th century Prussia.

\subsection{Data}

To investigate the effect of poverty on crime, we collected data on crime rates, rye prices, real wages, alcohol production, and weather conditions for all 12 Prussian provinces and the city of Berlin for the years 1882-1910. ${ }^{1}$ Crime statistics, based on the national German panel code from 1872, were computed by the Reichsjustizamt (Imperial Bureau of Justice) and published by the Kaiserliches Statistisches Amt (Imperial Statistical Office) from 1882 onwards. The statistics were published in a consistent way for each single year and are considered to be highly reliable (Johnson, 1995, p. 121). One shortcoming of the statistics is that they build upon court data: the

\footnotetext{
${ }^{1}$ Due to limited data availability, we had to exclude the Hohenzollern area (with a population of a mere 70,000) from our sample.
} 
computation of crime rates is based on convictions. Hence, our crime data differ from those used by MMT, who have access to reported cases from Bavarian police records, which is certainly a better measure for true crime.

From the official crime statistics, we computed annual crime rates for property crime (petty and grand larceny, robbery, and embezzlement) and violent crime (battery, simple and aggravated assault, gross indecency). ${ }^{2}$ Summery statistics are reported in Table 1. Between 1882 and 1910, there were on average more than 303 annual property crimes per 100,000 inhabitants. This is only slightly above the 298 yearly cases reported in MMT. Our data further show a violent crime rate of 178, which is clearly above the 55 annual cases covered in the Bavaria data. Given that these numbers capture only convictions, we conclude that 19th and early 20th century Prussia faced more property crime and considerably more violent crime than early 19th century Bavaria.

Following MMT, we use rye prices as our main proxy for poverty. Rye prices for the Prussian provinces were published annually by the Königlich-Preussisches Statistisches Landesamt (Prussian Statistical Office). The prices were not identical all over Prussia however, the rye market was very well integrated from the mid-19th century onwards and the rye prices are cointegrated for our sample period (Kopsidis, 1996). Nonetheless, market integration was not perfect. Consequently, our panel contains more information than a single time series.

Our second measures for the economic conditions is based on wage data (average day's wage) for unskilled male workers from 66 Prussian cities, spread over all provinces. The nominal wages are only available for a limited number of years (1884, 1892, 1902, and 1912). We linearly interpolated the wage data and deflated the nominal wages using an annual regional food price index. ${ }^{3}$ Hence, the fluctuations in real wages mainly stem from variation in the price level, with grain prices showing the largest changes over time. Admittedly, this real wage variable only gives an imprecise measure of the true real wages. In this sense, the variable is similar to the one used by MMT, the real wage for building craftsmen from one Bavarian city.

\footnotetext{
2 The classification closely follows MMT. Reclassifying robbery as a violent crime does not change any of our results, as the crime rate for robberies is only 0.8. (It is mainly larceny which drives the property crime rate.) Note further, that we did not conduct a separate analysis for murder and homicide, since the rate on these crimes is either zero or very close to zero in almost all province-year cells - a fact that is well documented in the literature (see, e.g., Johnson, 1995, p.134). Including murder and homicide in the violent crime category does not change any of our results.

${ }^{3}$ Regional price data were obtained from the Yearbooks of the Prussian Statistical Office. The weights for the price index were taken from the basket of consumer goods reported in Broadberry and Burhop (2010, p. 405).
} 
As a measure for beer consumption, we use the annual beer production in a province. Using this proxy seems reasonable, since beer was neither stored for longer periods nor was it traded over larger distances: during our sample period, the value-weight-ratio was quite low, i.e., relative transportation costs were quite high (Tappe, 1994, p. 222). Consequently, beer was produced all over Germany by thousands of breweries (Tappe, 1994, p. 225).

\section{Table 1 about here.}

Annual beer production data at the province level are available from records of the Biersteuer, a tax on malt grist used in beer production. The Prussian tax authorities closely monitored the amount of malt grist used by a brewery as well as the amount of beer produced. A detailed accounting of input and output was prescribed and tax authorities regularly and thoroughly audited brewers - not too surprisingly, since the beer tax was an important source of revenues. ${ }^{4}$ The figures from Table 1 show that the average annual beer production was 77 liters per-capita (which corresponds to roughly $70 \%$ of per-capita beer consumption in modern Germany). As reflected by the large standard error, beer production varied considerably between provinces as well as over time.

Finally, we collected monthly data on temperature and rainfall for 13 meteorological stations covering all provinces. From the monthly data, provided by the German and the Polish Meteorological Institutes (Deutscher Wetterdienst and Instytut Meteorologii i Gospodarki Wodnej), we computed annual, semi-annual and seasonal averages. Similar to the case of rye prices, temperature and rainfall are strongly co-integrated between the different provinces. Hence, the main source of variation in the weather variables is over time. Table 1 summarizes the key variables employed in our analysis.

\section{Empirical approach}

Equation (1) depicts the full model that is estimated in the following:

$$
\log (\text { Crime_k })_{\mathrm{jt}}=\alpha+\beta \log (\text { Rye price })_{\mathrm{jt}}+\gamma \log (\text { Beer })_{\mathrm{jt}}+\delta_{\mathrm{j}}+\lambda \text { Year }_{\mathrm{t}}+\varepsilon_{\mathrm{jt}}
$$

where the subscripts $j$ and $t$ denote provinces and years, respectively. As dependent variable, we use (the logarithm of) either the property or the violent crime rate, $k \in\{\mathrm{P}, \mathrm{V}\}$. The key variable of

\footnotetext{
${ }^{4}$ In 1881 , for instance, the beer tax revenues accounted for roughly 8 percent of total tax revenues in Germany.
} 
interest is the rye price. To assess the robustness of our findings, we will use log(Real wage), the real wage for unskilled male workers, as an alternative poverty measure. When we study the effect of poverty on violent crime, we also control for the per-capita beer production in a province. All specifications include a full set of province fixed effects and account for a time trend. $^{5}$

MMT carefully discuss the case of reversed causality, i.e. that poverty may not only induce crime, but that crime itself (e.g., the destruction of grain stores) affects economic conditions - in particular, rye and other grain prices and thus the real wages. To account for the potential endogeneity of the poverty measures, MMT propose an innovative identification strategy, using rainfall as instruments: weather conditions, in particular excessive rainfalls, sharply affect harvest yield and thus rye prices. We follow and refine their IV strategy, employing variation in rainfall and temperature within a (contemporary and lagged) year, measured at 13 meteorological stations covering the 13 Prussian provinces in our study. On the one hand, these more precise measures of weather conditions might provide for more powerful IVs than the annual average of rainfall used in MMT. On the other hand, Germany has undergone considerable land improvements (e.g., drainage systems) during the second half of the 19th century, which made the cultivation of rye less sensitive to weather conditions, in particular to excessive rainfall (Kopsidis, 1996). Hence, the IVs might be weaker for our sample period.

When we estimate the full model depicted in equation (1), we also use the weather instruments to account for the potential endogeneity of beer consumption. Next to rye, other grain prices - in particular barley, hops and wheat - are also sensitive to weather conditions. Moreover, the IV estimates that include present year temperature also capture the correlation between high temperatures and beer consumption. ${ }^{6}$

Since weather conditions per se might have a direct impact on our crime rates, one could question the validity of the exclusion restriction. To address this valid concern, we study the robustness of our results using a set of lagged weather instruments. Lagged weather affects past

\footnotetext{
${ }^{5}$ As quadratic and cubic trend terms turned out insignificant and hardly effected our estimates, we only included a linear time trend in the estimations reported below. Ideally, one would include a full set of year fixed effects. With this large number of year dummies, however, the estimation of cluster robust standard errors for 13 clusters becomes questionable. Moreover, in the 2SLS estimations, the inclusion of year fixed effects basically eliminates the power of our instruments. This is because the weather variables for a given year are highly correlated throughout Prussia (see Section 2). Including year fixed effects absorbs the key variation in rainfall and temperature over time, which considerably weakens our instruments.

${ }^{6}$ This channel is of course excluded once we use lagged weather variables.
} 
harvests, which in turn determines the supply of store grain and grain available for sowing and brewing. The lagged instruments should therefore affect current rye and beer prices, but there is no reason why the lagged IVs should be correlated with present crime rates. ${ }^{7}$

\section{Results}

We now turn to the results of our analysis. First, we present the first-stage estimations. Thereafter we discuss the impact of our poverty measures on property and violent crime.

\subsection{First-stage results}

As instrumental variables for the rye price and the real wage we use seasonal measures of rainfall from the current year, average rainfall from two lagged years and the average temperature in the current year. The estimation results reported in the first two columns of Table 2 show that these variables have a significant impact on the rye price and the real wage. Depending on the season, rainfall can either have a positive or a negative effect on rye prices. ${ }^{8}$ As in MMT, the one- and two-year lagged rainfall has a significantly positive effect on the rye price. Controlling for rainfall, the average temperature is negatively correlated with the rye price. For the real wages, the sign of the coefficients is always reversed - the intuition being that higher grain prices ceteris paribus reduce real wages. These estimates suggest that, despite land improvements, rye and other grain prices were still correlated with weather conditions during our sample period.

For the beer production we use a similar set of instruments: the seasonal measures of rainfall but also temperature in the warm (summer and fall) and cold (spring and winter) half of the year. Again, the IVs turn out to be strongly correlated with the beer variable. As compared to the estimates for the rye price reported in column (1), the coefficients for three of the four rainfall variables have the opposite sign. One might interpret this observation as supportive for the idea that times of high rye prices are also times of high beer prices - and thus lower beer consumption. The estimates from column (3) further show that the temperature during summer

\footnotetext{
${ }^{7}$ For all estimations we report cluster-robust standard errors. Due to the limited number of clusters (13 provinces), one might be concerned about the asymptotic approximations not being valid (Donald and Lang, 2007). To cope with this issue, we follow Cameron et al. (2008) and computed the significance levels of our parameter estimates following the wild cluster bootstrap procedure (imposing the null hypothesis and using 1000 replications; for an extension to IV methods, see Finlay and Magnusson, 2010). In each single regression reported below, the bootstrapping confirmed the reported significance level.

${ }^{8}$ If we replace the four seasonal rainfall variables with one single variable, the average rainfall in the contemporary year, the variable is positive but insignificant - exactly as in MMT.
} 
and fall has by far the strongest impact on beer production. A plausible explanation for this result is the fact that beer demand is substantially higher during a hot summer.

Table 2 further indicates that the correlation between the instrument variables and the three potentially endogenous regressors is quite strong. The F-statistics on the excluded instruments range from 14.1 to 15.6. Comparing these F-statistics to the critical values of the Stock-Yogo test (Stock and Yogo, 2002), one can clearly reject the null of weak instruments (a 2SLS bias exceeding $10 \%$ of the OLS bias). Although the first set of instruments is sufficiently strong to overcome the identification problem, one should be still concerned about a potential direct impact of weather conditions on crime. To tackle this issue, we will use an alternative set of instruments that excludes weather variables from the current year. First-stage results for these alternative estimations are presented in columns (4) - (6) of Table 2.

\section{Table 2 about here.}

When we exclude the present-year rainfall and temperature, the one- and two-year lagged annual and seasonal variation in rainfall have similar effects on the rye price (column 4) as well as on the real wage (column 5) as indicated by the estimates from columns (1) and (2), respectively. ${ }^{9}$ Some coefficients lose in terms of statistical significance others become even stronger and the overall strength of our IVs improves: using fewer instrument variables, the Fstatistics now reach 17.8 and 17.9, respectively. Regarding our third endogenous regressor, we only obtain a reasonably strong correlation with beer production when we use semiannual (rather than seasonal) information on lagged rainfall and lagged temperature. Using only lagged variables, one excludes the strong effect of current-year summer temperatures on thirsty Prussian beer drinkers (which was the strongest effect in the specification reported in column 3). Nevertheless, the one-year lagged summer and fall temperature still has a strong positive effect on the beer production. High temperatures during this period might either provide favorable conditions for harvesting and sowing of winter grain, or the present-year beer production is simply higher when last year's beer demand was high. In either case, we obtain a reasonably

\footnotetext{
${ }^{9}$ As the lagged temperature did not show a significant effect (neither on the rye price nor on the real wage), it was not included in this set of instruments.
} 
good F-statistic of 11.8. Hence, our lagged instruments are sufficiently strong to identify the causal effect of the poverty and beer measures on crime. ${ }^{10}$

\subsection{Poverty and property crime}

Table 3 reports our estimates of the impact of the different poverty measures on property crime. The 2SLS results are based on the first set of instruments, i.e., lagged and present-year weather. Columns (1) and (2) display the effect of the rye price estimated by OLS and 2SLS, respectively. The estimates reveal a significantly positive effect. The point estimates show a fairly stable elasticity of 0.21 and 0.26 , respectively. The IV estimates imply that a one standard deviation increase in the rye price leads to a $4 \%$ increase in property crime. The results confirm the findings from MMT, who obtained remarkably similar elasticities (in the range of 0.2 to 0.4 ). A notable difference concerns the comparison between OLS and 2SLS results. Once they instrument for the rye price, MMT estimate a considerably smaller elasticity, whereas our point estimates increase modestly. One possible explanation for this might be that the bias in our OLS estimation is smaller than in MMT, as we use panel data (accounting for province fixed effects) rather than a time series. ${ }^{11}$ In contrast to early 19th century Bavaria, the endogeneity of the rye price with respect to property crime might be less problematic for our Prussian panel data for the late 19th and early 20th century.

Table 3 about here.

Having established a significantly positive impact of rye prices on property crime, we next ask whether the effect is homogenous for the different Prussian provinces. While a higher rye price clearly translated into lower real incomes for urban workers, the effect on the rural population is less clear. In principle, higher rye prices could result in higher incomes for farmers with land holdings. It is quite unlikely that landless rural farm laborers would also benefit in this case. However, landless farm workers were typically provided board and lodging by the land owners who employed them. Moreover, the majority of the rural population who owned some land had at least some level of self-supply in food. Hence, higher rye prices should have a less

\footnotetext{
${ }^{10}$ To address any remaining concerns regarding the validity of the exclusion restrictions, we replicated all our results using only two year lagged weather variables. The estimates yielded very similar results. Not surprisingly, the instruments become less strong and the standard errors of the IV estimates increase.

${ }^{11}$ An alternative might be that our OLS fixed effects estimates are more sensitive to bias from measurement errors (see, e.g., Wooldridge, 2001, p.311), which would work against the ommited variable bias.
} 
pronounced effect on poverty - and thus on property crime - for rural as compared to the urban population.

To test this hypothesis, we include an interaction term in specification (3) and (4), which allows for a different effect of the rye price in provinces with a large agrarian sector. ${ }^{12}$ Based on occupation data for 1895, we consider all provinces with an above median share of employment in the agricultural sector as agrarian. ${ }^{13}$ According to our hypothesis, the interaction term should be negative. This is exactly what we find in the OLS estimation reported in column (3). For the overall effect, we obtain a highly significant elasticity of 0.30 . For the agrarian provinces, the effect of the rye prices is reduced by more than half, with the interaction effect being significant at the $5 \%$ level. When we instrument for the rye price (treating the direct and the indirect effect as endogenous regressors), we obtain qualitatively similar coefficients, however, they become insignificant. Our IVs appear too weak to identify the effect for two potentially endogenous regressors: as reported in column (4), the F-statistic drops to 4.08 and the standard errors become quite large. Hence, only the OLS estimates provide evidence supporting the hypothesis that the impact of rye prices on property crime is less pronounced for the predominantly rural provinces.

Let us now consider the effect of the real wage as an alternative indicator of economic hardship. In line with our earlier findings, the estimations identify a strong, negative and highly significant effect of the real wage on property crime. ${ }^{14}$ Columns (5) and (6) report a negative elasticity of 0.48 (for OLS) and 0.70 (2SLS), respectively. The latter elasticity implies that a one standard deviation increase in the real wage decreases property crime by $11 \%$. Despite working with panel data for a different sample period and a different part of Germany and despite the difference in the real wage measure, our point estimates are again very close to those reported in MMT (-0.4 to -1.0). One might interpret this similarity as an indicator for the fact that the causal link between poverty and property crime remained qualitatively and quantitatively quite robust in 19th and early 20th century Germany.

\footnotetext{
${ }^{12}$ As province-level fixed effects are included in the specification, we do not have to account for a (non-interacted) main effect for the agrarian provinces.

${ }^{13}$ This identifies seven agrarian provinces (Brandenburg, Hanover, East Prussia, Pomerania, Posen, Silesia and West Prussia), with an occupation share of roughly $50 \%$ of all documented occupations in the agrarian sector (as compared to approximately 25\% for the other provinces). Additional occupational data for the years 1882 and 1907 suggest that, while the occupational structure changed over time, the ranking according to the fraction of agrarian occupation remained basically constant.

${ }^{14}$ We also considered interaction effects for the real wage, but did not find any evidence on a heterogeneous effect.
} 
To address concerns regarding the validity of the exclusion restriction, we replicated the IV estimates from Table 3 using our second set of instruments, i.e., only the lagged weather variables. The results, reported in columns (1) - (3) of Table 5, confirm the earlier findings. For the two rye price estimations, the point estimates are virtually identical to those reported in Table 3. For the real wage, the lagged instrument yield a slightly higher elasticity (in absolute terms) which might be due to increased strength of our IVs (in terms of a higher F-statistic). In any case, the alternative set of IVs confirms the negative link between poverty and property crime.

\subsection{Poverty and violent crime}

Let us now turn to the effect of poverty on violent crime. Table 4 reports estimation results from different specifications that also account for beer production. The IV estimates are based on the set of lagged and present-year weather instruments discussed in section 4.1. The specification displayed in column (1) shows a highly significant negative effect of the rye price on violent crime. The 2SLS estimation from column (4) confirms this result, indicating an elasticity of -0.51. The point estimates from the Prussian panel data are again very close to those from MMT (ranging from -0.37 to -0.48 ). Hence, our estimates replicate the counterintuitive finding that a higher rye price leads to less violent crime. ${ }^{15}$

In explaining the robust negative correlation of rye prices and violent crime, MMT argue that "higher rye prices led to higher beer prices, and that the resulting drop in alcohol consumption in turn reduced violent crime” (MMT, p.385). We confront this conjecture with the data, including the beer production as a proxy for beer consumption in our estimates. ${ }^{16}$ In a first step, we studied the correlation between beer production and the rye price. Estimations that account for province fixed effects and time trends yield a highly significant negative correlation (not reported). Hence, beer consumption indeed declined when the rye price increased. In fact, the correlation extends to the price index used as deflator to compute the real wage. A likely interpretation of this observation is the fact that higher grain prices, which are a key determinant of the price index, are also correlated with beer prices.

\footnotetext{
${ }^{15}$ As for the case of property crime, we also considered potentially heterogeneous effects for the different types of province. In the case of violent crime, we did not detect any significant differences between more or less agrarian provinces.

${ }^{16}$ We also included the beer variable in estimates on property crime discussed above. The variable turned out to be insignificant and had no effect on our other results. See Burhop and Traxler (2010) for a closer discussion of the effect of alcohol on crime in Prussia.
} 
In a next step, we consider the direct effect of beer on violent crime. OLS and 2SLS estimations in columns (2) and (5) show a very strong and highly significant positive effect of beer production on violent crime. ${ }^{17}$ The elasticity of 0.8 suggests that a one standard deviation increase in the beer production - corresponding to a boost by an enormous 32 liters per-capita (from an average of 77 liters) - would result in a 38\% increase in violent crime. This result as well as the correlation between the rye price and our beer measure noted above provide the first two pieces of evidence supporting the conjecture of MMT: the consumption of beer played a crucial role in determining violent crime in Germany and the beer consumption was correlated with the rye price.

Putting things together, we now estimate the effect of the rye price controlling for beer production. The OLS results from column (3) indicate that the strong effect of beer remains roughly unchanged, whereas the impact of the rye price decreases substantially: when we control for beer production, the estimated elasticity increases from -0.44 (column 1) to -0.27 . Nevertheless, the effect is still significant at the $1 \%$ level. The picture changes when we consider the 2SLS results, reported in column (6). The IV estimates again confirm the strong effect of the beer measure, however, the elasticity of violent crime with respect to the rye price increases sharply from -0.51 (column 4) to -0.18 . Moreover, the effect is only significant at a weak $10 \%$ level. ${ }^{18}$

\section{Table 4 about here.}

Using the real wage as an alternative poverty measure confirms these findings: OLS and 2SLS coefficients from columns (7) and (9), respectively, indicate a substantial effect on violent crime, with an elasticity above one. Again, controlling for beer production has a substantial impact on the estimated coefficient for the wage variable: comparing the OLS estimates, the elasticity decreases from 1.17 to 0.71 in column (8). In the 2SLS regressions (where we instrument for the wage and the beer variable), the coefficient falls by roughly two thirds, from 1.14 to 0.48 in column (10). The effect remains significant at the $5 \%$ level. Note, however, that

\footnotetext{
${ }^{17}$ The observation that the OLS and 2SLS estimations yield similar coefficients might be attributed to the fact that the measurement bias - which runs against the potential bias from omitted variables - is aggravated in the context of OLS fixed effect estimations (Wooldridge, 2001, p.311).

${ }^{18}$ Note that we treat both the rye price and beer production as endogenous. With two endogenous regressors, the Fstatistics drops to 9.42. This value is only slightly below the Stock-Yogo critical values to reject the null of weak instruments with a 2SLS bias exceeding $10 \%$ of the OLS bias. When we only instrument for the rye price but not for beer, we obtain similar coefficients with an F-statistic of 14.
} 
the performance of the IVs is relatively poor in this estimation. When we treat both real wage and beer production as endogenous, the F-statistic drops to $7.02 .{ }^{19}$ Hence, one should treat this last result with caution.

Finally, we re-run all 2SLS estimations from Table 4, using the second set of instruments that excludes any contemporary weather variables. The estimation outcome is reported in columns (4) - (8) in Table 5. As compared to our analysis of property crime, where the estimated coefficients hardly differed between the two different sets of instruments, we now find slightly stronger differences on the estimated coefficients for the poverty measures and the beer variable. Hence, concerns regarding the exclusion restriction seem to be more warranted when we study violent crime.

In column (4) of Table 5, we omit beer production and obtain a highly significant elasticity of -0.39 (as compared to -0.51 in column (4) of Table 4). However, once we control for beer production, the IV estimates in column (6) show an insignificant coefficient for the rye price of $-0.10 .^{20} \mathrm{~A}$ similar pattern emerges when we replace the rye price with the real wage. Neglecting the role of beer consumption, the estimates from column (7) show a strong, positive effect of the wage on violent crime. Including beer production, the elasticity shrinks from 0.86 to an insignificant 0.12 in column (8). Regarding the strength of the instruments, the same caveat as above applies, as the F-statistic for the excluded IVs is considerably below 10.

\section{Table 5 about here.}

Summing up, our evidence confirms the interpretation put forward by MMT. The counterintuitive positive effect of the rye price (negative effect of the real wage) on violent crime seems to be driven by the correlation of rye and grain prices with beer consumption. Once we control for beer production as a measure for beer consumption, the impact of the poverty measures strongly decreases. In two out of four estimations, the effect is insignificant and only borderline significant in one of the other cases. Hence, poverty per se seems to have no causal effect on violent crimes.

\footnotetext{
${ }^{19}$ The Stock-Yogo test only rejects the null of a 2SLS bias exceeding $20 \%$ of the OLS bias.

${ }^{20}$ Given the fact that we use the set of lagged weather instruments and treat two regressors as endogenous, our IVs perform relatively well, as indicated by an F-statistic of 9.42 .
} 


\section{Concluding discussion}

This paper re-examined the causal effect of poverty on crime for late 19th and early 20th century Germany. The results confirm those from Mehlum, Miguel, and Torvik (2006). Following their IV strategy, we use exogenous variation in rye and grain prices induced by weather conditions (contemporary and lagged measures of rainfall and temperature) to identify the causal impact of poverty on crime. Based on province-level panel data for the years 1882-1910, we find a significantly positive effect of poverty on property crime. We also replicate the strong negative effect of poverty on violent crime observed by MMT. The authors conjectured that this puzzling finding is driven by an omitted variable: beer prices and thus beer consumption is correlated with the rye price and at the same time with violent crime. Our evidence strongly supports this interpretation. Using beer production as a proxy for consumption, we estimate a strong positive effect of beer on violent crime. Controlling for beer production, the poverty measures lose their significant negative effect. Hence, as argued by MMT, poverty per se does not have a causal effect on violent crime in 19th century Germany.

The observation that instruments, which appear credible at first, deliver misleading results due to correlation with an omitted variable, relates this study to the work by Raphael and WinterEbmer (2001). Identifying the effect of unemployment on crime, they document a similar case, where instruments for unemployment appear to be correlated with the unobserved frequency of interactions of potential victims and offenders. Thus, as noted by Raphael and Winter-Ebmer, their 2SLS estimates indicate a misleading negative effect of unemployment on murder and rape. These cases once more highlight an important pitfall in instrumental variable estimations and demonstrate the importance of a thorough validation of exclusion restrictions for a convincing identification strategy.

\section{References}

Blasius, Dirk (1976), Bürgerliche Gesellschaft und Kriminalität, Vandenhoeck \& Ruprecht, Göttingen.

Broadberry, Stephen and Carsten Burhop (2010), Real Wages and Labor Productivity in Britain and Germany, 1871-1938: A Unified Approach to the International Comparison of Living Standards, Journal of Economic History, 70(2), 400-427. 
Burhop, Carsten and Christian Traxler (2010), Beer, Booze and Brawls: Evidence on the Causal Effect of Alcohol on Crime for Prussia, 1882-1913. Max Planck Institute for Research on Collective Goods, Mimeo.

Cameron, A. Colin, Jonah B. Gelbach and Douglas L. Miller (2008), Bootstrap-Based Improvements for Inference with Clustered Errors, Review of Economics and Statistics, 90(3), 414-427.

Donald, Stephen G. and Kevin Lang (2007), Inference with Difference-in-Differences and Other Panel Data, Review of Economics and Statistics, 89(2), 221-233.

Finlay, Keith and Leandro M. Magnusson (2010), Bootstrap Methods for Inference with ClusterSample IV Models, Mimeo, Tulane University.

Johnson, Eric A. (1995), Urbanization and crime: Germany 1871-1914, Cambridge University Press, Cambridge.

Kopsidis, Michael (1996), Marktintegration und Entwicklung der westfälischen Landwirtschaft 1780-1880, Münsteraner Beiträge zur Cliometrie und quantitativen Wirtschaftsgeschichte III, Lit, Münster.

Markowitz, Sara (2005), Alcohol, Drugs and Violent Crime, International Review of Law and Economics, 25(1), 20-44.

Mehlum, Halvor, Edward Miguel and Ragnar Torvik (2006), Poverty and crime in 19th century Germany, Journal of Urban Economics, 59(3), 370-388.

Raphael, Steven and Rudolf Winter-Ebmer (2001), Identifying the Effect of Unemployment on Crime, Journal of Law and Economics, 44(1), 259-283.

Stock, James H. and Motohiro Yogo (2002), Testing for Weak Instruments in Linear IV Regression, NBER Technical Working Paper No. 284.

Tappe, Heinrich (1994), Auf dem Weg zur modernen Alkoholkultur, Steiner, Stuttgart.

Wooldridge, Jeffrey M. (2001), Econometric Analysis of Cross Section and Panel Data, MIT Press, MA.

Zehr, Howard (1976), Crime and the development of the modern society, Croom Helm, London. 


\begin{tabular}{lcccccc}
\hline & Mean & Std.Dev. & Min & Max & N & Years \\
\hline Property crime & 303.16 & 129.98 & 130.91 & 764.41 & 377 & $1882-1910$ \\
Violent crime & 178.19 & 55.42 & 50.99 & 304.00 & 377 & $1882-1910$ \\
Rye price & 14.73 & 2.21 & 10.8 & 21.6 & 377 & $1882-1910$ \\
Real wage & 2.22 & 0.31 & 1.31 & 2.89 & 377 & $1882-1910$ \\
Beer & 77.06 & 31.56 & 22.29 & 146.67 & 377 & $1882-1910$ \\
rain (annual) & 52.21 & 11.25 & 27.5 & 95.4 & 390 & $1881-1910$ \\
rain_s1 (spring) & 46.27 & 14.74 & 12.4 & 93.3 & 390 & $1881-1910$ \\
rain_s2 (summer) & 70.60 & 21.17 & 27.6 & 132.7 & 390 & $1881-1910$ \\
rain_s3 (fall) & 50.94 & 19.29 & 13.1 & 127.9 & 390 & $1881-1910$ \\
rain_s4 (winter) & 40.86 & 15.97 & 11 & 108.8 & 390 & $1881-1910$ \\
temp (annual) & 8.37 & 0.84 & 6.2 & 10.45 & 390 & $1881-1910$ \\
temp_h1 (spring+winter) & 3.93 & 1.33 & 0.4 & 6.75 & 390 & $1881-1910$ \\
temp_h2 (summer+fall) & 12.80 & 0.75 & 10.6 & 14.8 & 390 & $1881-1910$ \\
& & & & & & \\
\hline
\end{tabular}

Notes: Crime rates are annual cases per 100,000 population. Rye prices are in Pfennig per kilo. Real wages in Mark per day, with the underlying price index normalized to unity for 1900. Beer production is in liter per capital. The rainfall and temperature variables are based on average monthly precipitation in milimeters and temperature in degree Celsius, respectively.

Data Sources: Crime Data : Kaiserliches Statistisches Amt, Statistik des Deutschen Reichs, Neue Folge, Volumes 8, 23, 30, 37, 45, 52, 58, 64, 71, 77, 83, 89, 95, 120, 126, 132, 139, 146, 155, 162, 169, 176, 185, 193, 228, 237, 247; von Puttkamer \& Mühlbrecht, Berlin, various years. Price data for the years 1882-1906: Königlich-Preußisches Statistisches Landesamt, Besondere Beilage zur Zeitschrift des Königlich-Preußischen Statistischen Landesamts, Vol. 47 (1907). For the years 1907-1910: Königlich-Preußisches Statistisches Landesamt, Zeitschrift des Königlich-Preußischen Statistischen Landesamts, Vols. 48, 49, 50, and 51. Wage data: Amtliche Veröffentlichungen des Deutschen Städtetages, Statistisches Jahrbuch deutscher Städte, Fischer, Jena, various years. Beer data for 1882 - 1890: Kaiserliches Statistisches Amt, Monatshefte zur Statistik des Deutschen Reichs, Berlin. Since 1891: Kaiserliches Statistisches Amt, Vierteljahreshefte zur Statistik des Deutschen Reichs, Berlin. Weather data: German and Polish Weather Insititute, respectively (Deutscher Wetterdienst, Instytut Meteorologii i Gospodarki Wodnej). 
Table 2. First-stage estimations

\begin{tabular}{|c|c|c|c|c|c|c|c|}
\hline Dependent variable: & $\log$ (Rye price) & $\log ($ Real wage $)$ & $\log ($ Beer $)$ & & $\log$ (Rye price) & $\log ($ Real wage $)$ & $\log ($ Beer $)$ \\
\hline & \multicolumn{3}{|c|}{ present \& lagged instruments } & & \multicolumn{3}{|c|}{ lagged instruments } \\
\hline & $(1)$ & $(2)$ & (3) & & $(4)$ & $(5)$ & $(6)$ \\
\hline rain_s1 & $\begin{array}{c}-0.0015^{* * *} \\
{[0.0005]}\end{array}$ & $\begin{array}{c}0.0011^{* * *} \\
{[0.0003]}\end{array}$ & $\begin{array}{c}0.0019^{* * *} \\
{[0.0004]}\end{array}$ & L1.rain_s1 & $\begin{array}{c}0.0005 \\
{[0.0005]}\end{array}$ & $\begin{array}{c}0.0004 \\
{[0.0003]}\end{array}$ & \\
\hline rain_s2 & $\begin{array}{c}0.0018^{* * *} \\
{[0.0003]}\end{array}$ & $\begin{array}{c}-0.0010^{* * *} \\
{[0.0002]}\end{array}$ & $\begin{array}{c}-0.0006^{* * *} \\
{[0.0002]}\end{array}$ & L1.rain_s2 & $\begin{array}{c}0.0022^{* * *} \\
{[0.0004]}\end{array}$ & $\begin{array}{c}-0.0012^{* * *} \\
{[0.0002]}\end{array}$ & \\
\hline rain_s3 & $\begin{array}{c}-0.0026 * * * \\
{[0.0002]}\end{array}$ & $\begin{array}{c}0.0011^{* * *} \\
{[0.0002]}\end{array}$ & $\begin{array}{c}-0.0006 * * \\
{[0.0002]}\end{array}$ & L1.rain_s3 & $\begin{array}{c}-0.0016^{* * *} \\
{[0.0003]}\end{array}$ & $\begin{array}{c}0.0006^{* * *} \\
{[0.0002]}\end{array}$ & \\
\hline rain_s4 & $\begin{array}{c}-0.0007^{*} \\
{[0.0004]}\end{array}$ & $\begin{array}{c}0.0004^{*} \\
{[0.0002]}\end{array}$ & $\begin{array}{c}0.0007 \\
{[0.0005]}\end{array}$ & L1.rain_s4 & $\begin{array}{c}-0.0025^{* * *} \\
{[0.0005]}\end{array}$ & $\begin{array}{c}0.0016^{* * *} \\
{[0.0003]}\end{array}$ & \\
\hline L1.rain & $\begin{array}{l}0.0037 * * \\
{[0.0014]}\end{array}$ & $\begin{array}{c}-0.0019^{* *} \\
{[0.0007]}\end{array}$ & & L2.rain & $\begin{array}{c}0.0039 * * * \\
{[0.0013]}\end{array}$ & $\begin{array}{l}-0.0013^{*} \\
{[0.0006]}\end{array}$ & \\
\hline L2.rain & $\begin{array}{l}0.0031^{* *} \\
{[0.0013]}\end{array}$ & $\begin{array}{c}-0.0008 \\
{[0.0006]}\end{array}$ & & L1.rain_h1 & & & $\begin{array}{c}0.0031^{* * *} \\
{[0.0006]}\end{array}$ \\
\hline temp & $\begin{array}{c}-0.0466 * * * \\
{[0.0035]}\end{array}$ & $\begin{array}{c}0.0199 * * * \\
{[0.0026]}\end{array}$ & & L1.rain_h2 & & & $\begin{array}{c}-0.0007 * * * \\
{[0.0002]}\end{array}$ \\
\hline temp_h1 & & & $\begin{array}{c}-0.0121^{* *} \\
{[0.0044]}\end{array}$ & L1.temp_h1 & & & $\begin{array}{c}0.0052 \\
{[0.0035]}\end{array}$ \\
\hline temp_h2 & & & $\begin{array}{c}0.0726 * * * \\
{[0.0081]}\end{array}$ & L1.temp_h2 & & & $\begin{array}{c}0.0529 * * * \\
{[0.0070]}\end{array}$ \\
\hline Observations & 364 & 364 & 377 & & 364 & 364 & 377 \\
\hline R-squared & 0.278 & 0.552 & 0.503 & & 0.243 & 0.542 & 0.456 \\
\hline F-statistic & 15.630 & 14.108 & 14.179 & & 17.834 & 17.929 & 11.801 \\
\hline
\end{tabular}

Notes: All estimations include province fixed effects and a time trend. Robust standard errors, clustered at the province level are reported in squared brackets. L1 and L2 indicate one and two year lagged variables. F-statistics valid for i.i.d. errors. Significance levels are indicated by *** (1\%),

** (5\%) and * (10\%). 
Table 3. Property crime - fixed effects estimations (OLS and 2SLS)

\begin{tabular}{|c|c|c|c|c|c|c|}
\hline Dependent variable: & $\log ($ Crime_P $)$ & & & & & \\
\hline & $(1)$ & $(2)$ & $(3)$ & $(4)$ & $(5)$ & $(6)$ \\
\hline & OLS & 2SLS & OLS & 2SLS & OLS & 2SLS \\
\hline log(Rye price) & $\begin{array}{c}0.206^{* * *} \\
{[0.043]}\end{array}$ & $\begin{array}{l}0.265^{* *} \\
{[0.099]}\end{array}$ & $\begin{array}{c}0.302 * * * \\
{[0.048]}\end{array}$ & $\begin{array}{c}0.488 \\
{[0.310]}\end{array}$ & & \\
\hline $\log$ (Rye price) x Agri & & & $\begin{array}{c}-0.167 * * \\
{[0.065]}\end{array}$ & $\begin{array}{c}-0.362 \\
{[0.466]}\end{array}$ & & \\
\hline $\log$ (Real wage) & & & & & $\begin{array}{c}-0.480 * * * \\
{[0.102]}\end{array}$ & $\begin{array}{c}-0.700 * * * \\
{[0.199]}\end{array}$ \\
\hline Observations ( $\mathrm{N}$ x T) & 377 & 364 & 377 & 364 & 377 & 364 \\
\hline R-squared & 0.295 & 0.307 & 0.299 & 0.310 & 0.306 & 0.319 \\
\hline F-statistic (IVs) & - & 15.630 & - & 4.082 & - & 14.108 \\
\hline
\end{tabular}

Notes: All estimations include province fixed effects and a time trend. Robust standard errors, clustered at the province level, are reported in squared brackets. Significance levels are indicated by *** (1\%) and ** (5\%). 
Table 4. Violent crime - fixed effects estimations (OLS and 2SLS)

\begin{tabular}{|c|c|c|c|c|c|c|c|c|c|c|}
\hline \multicolumn{11}{|c|}{ Dependent variable: $\log ($ Crime_V $)$} \\
\hline \multirow[b]{3}{*}{ log(Rye price) } & $(1)$ & $(2)$ & (3) & $(4)$ & $(5)$ & $(6)$ & $(7)$ & $(8)$ & $(9)$ & $(10)$ \\
\hline & & OLS & & \multicolumn{3}{|c|}{ 2SLS } & \multicolumn{2}{|c|}{ OLS } & \multicolumn{2}{|c|}{ 2SLS } \\
\hline & $\begin{array}{c}-0.438^{* * *} \\
{[0.042]}\end{array}$ & & $\begin{array}{c}-0.268 * * * \\
{[0.044]}\end{array}$ & $\begin{array}{c}-0.506^{* * *} \\
{[0.072]}\end{array}$ & & $\begin{array}{c}-0.179 * \\
{[0.097]}\end{array}$ & & & & \\
\hline log(Real wage) & & & & & & & $\begin{array}{c}1.170 * * * \\
{[0.120]}\end{array}$ & $\begin{array}{c}0.706^{* * *} \\
{[0.109]}\end{array}$ & $\begin{array}{c}1.144^{* * *} \\
{[0.127]}\end{array}$ & $\begin{array}{c}0.479 * * \\
{[0.212]}\end{array}$ \\
\hline $\log$ (Beer) & & $\begin{array}{c}0.870 * * * \\
{[0.083]}\end{array}$ & $\begin{array}{c}0.796^{* * *} \\
{[0.086]}\end{array}$ & & $\begin{array}{c}0.847^{* * *} \\
{[0.130]}\end{array}$ & $\begin{array}{c}0.771^{* * *} \\
{[0.150]}\end{array}$ & & $\begin{array}{c}0.711^{* * *} \\
{[0.090]}\end{array}$ & & $\begin{array}{c}0.671 * * * \\
{[0.166]}\end{array}$ \\
\hline Observations & 377 & 377 & 377 & 364 & 377 & 377 & 377 & 377 & 364 & 377 \\
\hline R-squared & 0.542 & 0.707 & 0.735 & 0.479 & 0.707 & 0.731 & 0.615 & 0.754 & 0.557 & 0.747 \\
\hline F-statistic (IVs) & - & - & - & 15.630 & 14.179 & 9.416 & - & - & 14.108 & 7.015 \\
\hline
\end{tabular}

Notes: All estimations include province fixed effects and a time trend. Robust standard errors, clustered at the province level, are reported in squared brackets. Significance levels are indicated by *** $(1 \%), * *(5 \%)$ and * $(10 \%)$. 
Table 5. Property and violent crime - 2SLS estimations with lagged instruments

\begin{tabular}{|c|c|c|c|c|c|c|c|c|}
\hline \multirow[t]{2}{*}{ Dependent variable: } & \multicolumn{3}{|c|}{$\log ($ Crime_P $)$} & \multicolumn{5}{|c|}{$\log ($ Crime_V $)$} \\
\hline & $(1)$ & $(2)$ & (3) & (4) & (5) & $(6)$ & (7) & (8) \\
\hline $\log$ (Rye price) & $\begin{array}{c}0.273^{* * *} \\
{[0.065]}\end{array}$ & $\begin{array}{c}0.448 \\
{[0.281]}\end{array}$ & & $\begin{array}{c}-0.389 * * * \\
{[0.090]}\end{array}$ & & $\begin{array}{c}-0.097 \\
{[0.099]}\end{array}$ & & \\
\hline $\log$ (Rye price) x Agri & & $\begin{array}{c}-0.289 \\
{[0.463]}\end{array}$ & & & & & & \\
\hline log(Real wage) & & & $\begin{array}{c}-0.811 * * * \\
{[0.171]}\end{array}$ & & & & $\begin{array}{c}0.864 * * * \\
{[0.156]}\end{array}$ & $\begin{array}{c}0.123 \\
{[0.242]}\end{array}$ \\
\hline $\log ($ Beer $)$ & & & & & $\begin{array}{c}1.001^{* * *} \\
{[0.145]}\end{array}$ & $\begin{array}{c}0.946^{* * *} \\
{[0.165]}\end{array}$ & & $\begin{array}{c}0.924 * * * \\
{[0.213]}\end{array}$ \\
\hline Observations & 364 & 364 & 364 & 364 & 377 & 377 & 364 & 377 \\
\hline R-squared & 0.307 & 0.312 & 0.312 & 0.486 & 0.701 & 0.720 & 0.552 & 0.720 \\
\hline F-statistic (IVs) & 17.834 & 4.562 & 17.929 & 17.834 & 11.801 & 9.417 & 17.929 & 5.805 \\
\hline
\end{tabular}

Notes: All estimations include province fixed effects and a time trend. Robust standard errors clustered at the province level are reported in squared brackets. Significance levels are indicated by *** (1\%). 


\section{Preprints 2010}

2010/34: Dickert S., Herbig B., Glöckner A., Gansen C., Portack R., The More the Better? Effects of Training and Information Amount in Legal Judgments

2010/33: Glöckner A., Towfigh E. V., in preparation: Game Over. Empirical Support for Soccer Bets Regulation

2010/32: Glöckner A., Towfigh E. V., Geschicktes Glücksspiel. Die Sportwette als Grenzfall des Glücksspielrechts

2010/31: Hellwig M., Capital Regulation after the Crisis: Business as Usual?

2010/30: Prantl S., The Impact of Firm Entry Regulation on Long-living Entrants

forthcoming in: Small Business Economics, In Press.

2010/29: Engel C., Kurschilgen M., Fairness Ex Ante \& Ex Post - The Benefits of Renegotiation in Media Markets, Bonn, Max Planck Institute for Research on Collective Goods, 2010. Abstract Tagged BibTex XML Full Textapplication/pdf icon

2010/28: Goerg S. J., Walkowitz G., On the Prevalence of Framing Effects Across Subject-Pools in a Two- Person Cooperation Game

forthcoming in: Journal of Economic Psychology, In Press.

2010/27: Chmura T., Engel C., Englerth M., Pitz T., At the Mercy of the Prisoner Next Door. Using an Experimental Measure of Selfishness as a Criminological Tool

2010/26: Weinschenk P., Skill Formation under Incomplete Information

2010/25: Brilon S., Job Assignment with Multivariate Skills

2010/24: Lang M., Wambach A., The fog of fraud - mitigating fraud by strategic ambiguity

2010/23: Albanese G., Sorge M. M., The Role of the Judiciary in the Public Decision Making Process

2010/22: Bade S., Electoral Competition with Uncertainty Averse Parties

2010/21: Leifeld P., Haunss S., A Comparison between Political Claims Analysis and Discourse Network Analysis: The Case of Software Patents in the European Union

2010/20: Burhop C., Gelman S., Transaction costs, liquidity and expected returns at the Berlin Stock Exchange, 1892-1913

2010/19: Hellwig M., Finanzkrise und Reformbedarf [The Financial Crisis and Regulatory Reform], Bonn

2010/18: Bierbrauer F., Optimal Income Taxation and Public-Goods Provision with Preference and Productivity Shocks, Bonn 2010/17: Weinschenk P., Entry and Incumbent Innovation, Bonn

2010/16: Bierbrauer F., Boyer P. C., The Pareto-Frontier in a simple Mirrleesian model of income taxation

2010/15: Grechenig K., Sekyra M., No Derivative Shareholder Suits in Europe - A Model of Percentage Limits and Collusion

2010/14: Bierbrauer F., On the optimality of optimal income taxation

2010/13: Engel C., An Experimental Contribution to the Theory of Customary (International) Law

2010/12: Leifeld P., Schneider V., Institutional communication revisited: Preferences, opportunity structures and scientic expertise in policy networks

2010/11: Grechenig K., Nicklisch A., Thöni C., Punishment despite Reasonable Doubt - A Public Goods Experiment with Uncertainty over Contributions

2010/10: Petersen N., Braucht die Rechtswissenschaft eine empirische Wende?

2010/09: Bade S., Ambiguous Act Equilibria

2010/08: Lehmann S., Volckart O., The Political Economy of Agricultural Protection: Sweden 1887

2010/07: Engel C., Dictator Games: A Meta Study

2010/06: Engel C., Irlenbusch B., Turning the Lab into Jeremy Bentham’s Panopticon. The Effect of Punishment on Offenders and Non-Offenders 
2010/05: Gropp R., Hakenes H., Schnabel I., Competition, Risk-Shifting, and Public Bail-out Policies

2010/04: Slemrod J., Traxler C., Optimal observability in a linear income tax

2010/03: Baumann, Florian; Friehe, Tim; Grechenig, Kristoffel: Switching Consumers and Product Liability: On the Optimality of Incomplete Strict Liability

2010/02: Bierbrauer F., Hellwig M., Public-Good Provision in a Large Economy

2010/01: Bierbrauer F., Incomplete contracts and excludable public goods 